\title{
Special feature: varieties of capitalism, civil society, and welfare/environmental policies
}

\author{
Hiroyasu Uemura ${ }^{1} \cdot$ Hironori Tohyama ${ }^{2} \cdot$ Yuji Harada ${ }^{3}$ \\ Published online: 5 November 2019 \\ (c) Japan Association for Evolutionary Economics 2019
}

JEL Classification B15 $\cdot$ B55 $\cdot \mathrm{I} 38 \cdot \mathrm{P} 10 \cdot \mathrm{P} 51$

In Japan, 35 years have passed since American radical economics and the régulation theory came to influence political economy; further, it is 20 years since the varieties of capitalism approach were introduced to Japanese social sciences. Japanese political economists have developed theories by learning from these attractive theoretical framework and applied them to empirical studies of Japanese capitalism (Boyer and Yamada 2000). Around 1990, a worldwide collaborative research effort was organized by the World Institute of Developing Economics Research (WIDER) by tapping many prominent political economists to study postwar capitalism. Subsequently, a macroeconomic model that included work effort and labor institutions was created by Samuel Bowles and Robert Boyer-two of the leading political economists in the world (Bowles and Boyer 1988, 1990). In Japan, this type of Kaleckian model was recently applied to the analysis of "green growth" (Okuma 2017).

Following this, the varieties of capitalism also became an important research theme in our international collaborative research centered on the régulation theory (Boyer et al.2012; Boyer et al.2018). In particular, the varieties of Asian capitalism were studied by several Japanese political economists. Harada and Tohyama (2012) jointly investigated the institutional diversity of Asian capitalism and found that it had the following five types in the 2000s: insular semi-agrarian capitalism;

Hiroyasu Uemura

huemura@ynu.ac.jp

Hironori Tohyama

tohyama.hironori@shizuoka.ac.jp

Yuji Harada

yuji.harada@econ.setsunan.ac.jp

1 Graduate School of International Social Sciences, Yokohama National University, 79-4

Tokiwadai, Hodogaya-ku, Yokohama 240-8501, Japan

2 Department of Economics, Shizuoka University, Ohya 836 Suruga-ku, Shizuoka, Japan

3 Faculty of Economics, Setsunan University, 17-8 Ikedanaka-machi, Neyagawa City,

Osaka 572-8508, Japan 
trade-led industrializing capitalism; city capitalism; innovation-led capitalism; and continental mixed capitalism. They also showed that this institutional diversity was relatively stable, at least during 2004-2011, even as Asian economies grew rapidly. Their empirical studies also revealed that there is an association between industrial structure, technological systems underlying innovative activities, and the institutional diversity in Asian economies (Tohyama and Harada 2016, 2018). They have extended their earlier analysis to address the question of whether and how social preferences_-regarding trust and redistribution-are associated with institutional diversity to look into the possibility of civil society or public policies to advance it.

Moreover, Samuel Bowles and Robert Boyer have recently published books that synthesize their own research in The Moral Economy (Bowles 2016) ${ }^{1}$ and Économie politique des capitalismes (Boyer 2015), respectively. These new works should be properly situated in the tradition of the Japanese social sciences (Yamada et al. 2018; Yamada 2018).

This special feature tries to identify the significance of the results of recent research by Samuel Bowles and Robert Boyer; further, on the basis of their theoretical achievements, we consider the varieties of capitalism, the role of social preferences and trust, welfare policies, and environmental policies. In this regard, we focus on civil society and social preferences as an important basis to create better policies in contemporary capitalism. We also examine how discussions on civil society, as well as welfare and environmental policies, have developed in a specific way in Japan to create a more equitable and sustainable society. In addition, we include the book reviews of the abovementioned titles of Bowles and Boyer.

Hiroyasu Uemura, in his article, "Social preference and civil society in the institutional analysis of capitalisms: an attempt to integrate Samuel Bowles' "The Moral Economy and Robert Boyer's Régulation Theory" introduces Bowles' and Boyer's in-depth understanding of modern society and capitalism. The difference between their theories and the possibility of complementary relationships between them are considered. First, it is necessary to understand the formation of civic social preferences with multi-layered institutions and actors both inside and outside the market economy. Citizens' social preferences can potentially develop in a way that complements the market economy, supported by the rule of law and liberal institutions, as suggested by Bowles, as well as "civil society" in the régulation theory. This understanding is important in the labor market with incomplete contracts. Second, it is necessary to develop complementary analyses of the formation of citizens' preferences at the micro and macro levels. In Bowles' framework, the rule of law and civic institutions promote the development of civic social preferences by reducing market risks, and market risks and income distribution are determined by macroeconomic dynamics, as suggested by the régulation theory. Third, it is necessary to analyze democratic processes between legislators and citizens that are determined by the dynamic feedback of the political and economic domains. In promoting policymakers' preferences with the appreciation of citizenship and democracy, the

\footnotetext{
1 Bowles' (2004) is also a very important theoretical achievement that analyzes the coevolution of institutions and preferences by using the evolutionary game theory.
} 
political participation of citizens plays an important role, as suggested in Boyer's "civic social democracy."

Hironori Tohyama, in his article, "How does a liberalizing market influence a synergy between redistribution preference and social preference in Asian socioeconomies?," addresses the question of why Asian people are not in favor of demanding more welfare expenditure despite facing problems associated with growing economic inequality. He shows that, in the Asian case, the degree to which redistribution preference is associated with social preference could be lowered as the market space is liberalized. Thus, despite the exacerbation of income inequality, caused by the expansion of a liberal type of market space, Asian people refrain from demanding of their government that it undertake more redistributive expenditure.

Yuji Harada, in his article, "Diversity and transformation of institutional configurations and trust structures," conducts several empirical analyses to investigate the relationship between institutions at the national level and individuals' consciousness/ behavior at the micro level, in line with the literature on varieties of capitalism. He shows that not only the institutional configurations in advanced economies and those in Asia, but also their structures of trust, which are regarded as representing individuals' consciousness, remained diverse in the mid-2000s; this occurred even after the spread of market mechanisms in different domains, thereby belying the expectation of a convergence to a single model of institutional configuration and trust structure. There exists a certain degree of similarity between the types of institutional configurations and those of trust structures; this implies some sort of complementarity between these two levels. He also indicates that there is diachronic diversity in institutional configurations and trust structures, as well as synchronic diversity. His analysis reveals divergent paths in the transformation of trust structures since the 1980s. These paths correspond, to some extent, to the transformational patterns of institutional configurations. However, transformations of institutional configuration and trust structure do not strictly correspond with each other; thus, they support a hypothesis of loosely coupled institution-actor linkage.

Nanako Fujita, in her article, "Welfare society and welfare state in the Japanesetype discourse on civil society," reexamines the development of the Japanese-type civil society theory from the analytical perspective of "welfare." In postwar Japan, a company-centric society emerged and dramatic economic growth was achieved; further, the Japanese-type civil society theory came to uphold a center-left political ideology that examined the deficiencies of the Western-European-type welfare state and welfare state theory in Japan. However, the welfare theory in Japanese-type civil society theory ultimately lacked a positive welfare state theory. Fujita suggests that from the 1970s to the 1980s, the influence of "Japanese-type welfare society theory," which sought to bypass the welfare state and go directly to a welfare society, was observed; meanwhile, Kiyoaki Hirata's adoption of Gramsci can be considered as an turning point in the history of this discourse, and it witnessed Japanese-type civil society theory crossing swords with "new civil society theory."

Kazuhiro Okuma, in his article, "Potential mechanisms for the social regulation of the economies on global and local scales: an institutional analysis of ESG investment and community renewables," suggests that the ruling power of national institutions has weakened under economic globalization; this, in turn, leads to an 
important question - how can the social regulation of an economy be achieved in multilayered spatial scales ranging from local to global. Two movements-global ESG investment and local community renewables - that have recently emerged warrant attention as providing potential institutions for such regulation. Drawing on the régulation approach, this article analyzes these two movements to consider their significance and potential. ESG investment, driven by a coalition of NGOs and pension funds, reflects environmental and social concerns in global finance, which is the core of the current finance-led growth regime. Community renewables, meanwhile, by utilizing local natural resources through the participation of local residents, create businesses that contribute to entrepreneurial regional development, which has become necessary since the end of Fordism. Both of these can be understood as civil-society-led movements that directly incorporate environmental and social interests within dominant institutional forms under "glocalization." These two movements can be considered viable because they are compatible with current growth patterns. However, because both these movements depend on external factors, they cannot achieve transformative changes for sustainability on their own. Nevertheless, it is conceivable that individual/local actions and the global competitive environment could interact and produce cumulative change (i.e., they could coevolve). States will play an important role in this process by advancing such actions through national institutions.

Toshio Yamada, in his book review, "Samuel Bowles': The Moral Economy: Why Good Incentives Are No Substitute for Good Citizens," convincingly presents the fascinating aspects of this book; these include the crowding out of moral behavior by material incentives, and, more significantly, the possibility of crowding in, that is, viewing social preferences and incentives as complementary-each enhancing the effect of the other. This argument is in striking contrast to those in mainstream economics, where morality does not affect incentives and vice versa. In other words, the effect of the incentives is independent of the level of social preferences. Because the market economy, on its own, cannot produce a flourishing society, civic trust and moral sentiments should support it. A healthy market economy cannot be sustainable without civil society. After reviewing Bowles's arguments, he also looks into Japanese "civil society" thought and finds an idea that bears a striking resemblance to that of Bowles. It argues that "normal self-interest" leading to "social goods" is a type of self-interest possessed by ordinary citizens or ethical actors who internalize the "principal sympathy" and defend laws and justice. Yamada states that Samuel Bowles, the most illustrious successor to American liberals, and the best minds of civil society in postwar Japan, are in agreement with each other despite the historical distance.

Yuji Harada and Hiroyasu Uemura, in their book review, "Robert Boyer, Économie politique des capitalismes: Théorie de la régulation et des crises," show that the book presents the systematic framework of the régulation theory based on recent research by the network of political economists working along this paradigm. The essential objective of the theory is to provide an analysis of: the diverse and multi-level interactions between polity and economy in the different modes of régulation, and the international interdependence of growth regimes to investigate the diversity and dynamics of the varieties of capitalism. This review of the French book intends to help readers fully 
understand the academic essence of the book by carefully translating and interpreting French words and phrases in English. Further, the reviewers also emphasize the significance of the book with a systematic theoretical framework of the régulation theory in the context of Japanese social sciences.

This special feature states how Samuel Bowles and Robert Boyer have contributed to the development of political economy and institutional economics. In their recently published books, Bowles and Robert suggest that citizens' social preferences and norms can potentially develop in a way that complements and coordiantes the capitalist market economy, supported by the rule of law and liberal institutions, as well as the political processes in "civil society." Based on their arguments, this special issue sheds light on civil society, social preferences, and trust, as well as the social regulation of economies in the Asian context. The contributions that focus on trust and social preferences suggest that an institutional context matters in understanding social preferences, and raises a hypothesis of loosely coupled institution-actor linkage based on empirical findings that suggest that the transformations of institutional configuration and trust structure do not strictly correspond to each other.

The contributions focusing on "civil society thought" and "welfare state theory" in Japanese social sciences show theoretical similarity between Japanese "civil society thought" and Bowles' "the moral economy" and Boyer's "civil society." However, a positive western-type welfare state theory was rarely seen in the welfare theory in Japanese-type civil society theory. Therefore, we should consider deeply that good, morally motivated people_-good citizens - are indispensable for civil society and welfare on the basis of socio-political processes in the dynamics of a growth regime. The contribution analyzing social regulations on economies by focusing on ESG investment and local community renewables suggests that these two movements, which can be referred to as citizens-led, could affect currently dominant institutional forms. This also means that national institutions could play crucial roles in economic coordination by complementing local and global institutions.

Thus, the special feature suggests that civil society, good citizens, and their underlying social preferences, which are loosely coupled with national institutions, play a significant role in creating better public policies.

\section{Compliance with ethical standards}

Conflict of interest There is no conflict of interest.

Ethical approval This article does not contain any studies with human participants or animals performed by the author.

\section{References}

Bowles S (2004) Microeconomics: behavior, institutions and evolution. Princeton University Press, New Jersey 
Bowles S (2016) The moral economy: why good incentives are no substitute for good citizens. Yale University Press, New Haven

Bowles S, Boyer R (1988) Labor discipline and aggregate demand: a macroeconomic model. Am Econ Rev 78(2):395-400

Bowles S, Boyer R (1990) A wage-led employment regime: income distribution, labor discipline, and aggregate demand in welfare capitalism. Oxford University Press, Oxford

Boyer R (2015) Économie politique des capitalismes: théorie de la régulation et des crises. La Découverte, Paris

Boyer R, Yamada T (eds) (2000) Japanese capitalism in crisis: a regulationist interpretation. Routledge, London

Boyer R, Uemura H, Isogai A (2012) En français: Capitalismes asiatiques: Diversité et transformations. Presses universitaires de Rennes, Remmes, 2015. Diversity and transformations of Asian capitalisms. Routledge, Abingdon

Boyer R, Uemura H, Yamada H, Song L (eds) (2018) Evolving diversity and interdependence of capitalisms: transformations of regional integration in EU and Asia. Springer, Tokyo

Harada Y, Tohyama H (2012) Asian capitalisms: institutional configurations and firm heterogeneity. In: Boyer et al (2012)

Okuma K (2017) The evolving relationship between economy and environment: theory and the Japanese experience. Springer, Tokyo

Tohyama H, Harada Y (2016) Diversity of institutional architecture underlying the technological system in Asian economies. Evolut Inst Econ Rev 13(1):239-268

Tohyama H, Harada Y (2018) Institutional diversity, industrial and innovative specialization in Asian capitalism. In: Boyer R, Uemura H, Yamada T, Song L (eds) Evolving diversity and interdependence of capitalisms Evolutionary economics and social complexity science, vol 11. Springer, Tokyo, pp 333-359

Yamada T (2019) Contemporary capitalism and civil society: the Japanese experience. Springer, Berlin

Yamada T, Uemura H, Harada Y, Fujita N (2018) Civil society and democracy: the régulation approach. Fujiwara-shoten, Tokyo

Publisher's Note Springer Nature remains neutral with regard to jurisdictional claims in published maps and institutional affiliations. 